\title{
Strategy and management, the foundations of any successful brand
}

\author{
Recibido: 7 de febrero de 2019 \\ Aceptado: 23 de abril de 2019 \\ Publicado: 24 de junio de 2019
}

\author{
Santiago Mayorga Escalada \\ smayorgaes.com@upsa.es \\ Universidad Pontificia de Salamanca (España)
}

\begin{abstract}
Resumen: Al analizar cualquier trabajo de marca tendemos a simplificar un proceso que, por su naturaleza, es enormemente complejo y multidisciplinar. Existe una corriente de opinión mayoritaria que se empeña en reducir el proceso de creación de una marca a su logotipo, o al grupo de elementos que articularán la identidad visual en una especie de imagen cosmética, puramente estética. Se reduce la concepción del branding a un gasto superficial, no a una inversión estratégica. Este aspecto evidencia por regla general una relevante falta de medios, profesionales y planificación de objetivos puestos en el largo plazo lo que acaba por devaluar, en muchos casos, la propia promesa de la marca. Estas cuestiones quedan en evidencia cuando no se pone en marcha un proceso profesional de construcción de marca de una forma estudiada, seria y coherente.
\end{abstract}

Palabras clave: Marcas, gestión, estrategia, gestión de marcas, branding.

Abstract: When analyzing any branding work we tend to simplify a process that by its nature is enormously complex and multidisciplinary. There is an important current of opinion that tends to reduce the creation of a brand to its logo or to the group of elements that will articulate the visual identity in a sort of cosmetic image, or purely aesthetic. Either by understanding branding as a superficial expense and not as a strategic investment, due to ignorance of the discipline, short-sightedness, lack of means and / or professionals or, by a mixture of all these factors, the brands themselves devalue in many cases from the moment they make the decision not to face their construction in a studied way, serious and coherent.

Key words: Brands, Management, Strategy, Brand Management, Branding. 


\section{Introduction}

The main line of research focuses on the study of brand management, both from the professional sector and from the academic field, with the aim of offering a series of master lines that facilitate an increasingly specialized teaching action around the discipline within the scope of university degrees in advertising, marketing and communication. Improve the theoretical-practical training of students in everything that has to do with the process of management of brands that in the future develops more easily in their professional role, adapting efficiently to the demands of the sector.

To obey the line of research proposed, it is necessary to develop a constant analysis study, focusing on the main characteristics that shape the brand management process. It is also relevant for the study to identify the agents that participate in the process, the elements that compose it, the structure that gives it shape, and the functional methodology that normalizes the performance of this task. Through this torrent of information, we will be able to obtain a definition of the discipline and we will know what his true influence is. The study must always take into account the dichotomy between the reality of the professional sector and that of the academic field, in the same way that a double perspective is generated between the local/national level and the accumulation of knowledge produced in a global way. Last but not least for the correct understanding of the brand management process, there is the temporal scope, taking into account that it is important to adapt to the future from an efficient action in the present, knowing very well all the baggage of the past.

The main personal and academic motivation when it comes to advancing in the study of brand management is that it is currently a process that, in one way or another, is found in all areas of our society. Brands have become the most important asset that corporations have (Clifton, 2009), becoming the main element when it comes to connecting with the public in a relevant way. The leading role that the brand currently occupies is evident both in the commercial sphere and when observing the different advertising elements that surround us everywhere and at all times. Everything happens to become a brand, and brands go beyond the purely commercial field to project their significance and influence towards the social and cultural domain. The role of symbolic construction exercised by the brand on people, and the image that is generated from them, becomes a transversal force that reaches any area of action or decision making that develops within the first Western world.

The current leading role played by brands is established thanks to its historical capacity for adaptation over the centuries. They conform as an indissoluble agent that is linked to the development of different human civilizations, chasing people in their need to improve trade, the exchange of goods or the recognition of business and products. Its importance suffers a really exponential growth with the Industrial Revolution and the arrival of chain production. The market grows, production increases and competition reinforce the fact of incorporating brands that help differentiate themselves from the rest. The twentieth century is a race forward in the birth and development of commercial techniques that bring the brand to gain more and more value, generally connected to the offer of a particular product (Aaker, 2012). Social changes and technological development that exists since the late 
twentieth century and that are strengthened with the arrival of the 21 st century, bring with them a series of disruptive changes that end with paradigms that had been consolidated over decades. Industry 4.0, technological democratization and advances in communication build new logics of production, consumption or purchase decision making. The acceleration of time in processes, immediacy or uncertainty are characteristics that put us before a new way of understanding the world. We find ourselves with a conjuncture where the concept of liquidity prevails in a general way and in all senses (Bauman, 2007).

Under these new parameters the brand stands as an unquestionable protagonist and as a point of direct connection with users (empowered agent around which the action of the brand currently revolves). Its ability to adapt to changes allows it to become an ideal solution for companies/corporations facing new paradigmatic challenges. The strategic aspect becomes the star element of differentiation when it comes to establishing a successful brand management process where it is possible to incorporate multiple elements belonging to management, communication, marketing, etc.

\section{Objectives and methodology}

From the present investigation it is intended to make a theoretical review to the main experts in brand management to verify its strategic nature. To achieve this, we will use two essential axes: professional sector/academic field and national/international theoretical production.

Benavides (2017) emphasizes the imperative need to further research on brand management from the field of strategic communication. The author also adds that brand management has a strong problem associated with its multidisciplinary nature. On the one hand we find generic problems linked to any phenomenon studied from the field of Social Sciences and on the other hand we observe a large number of specific problems resulting from a study of the subject carried out from different fields and interests. It is very common to find a bibliography related to brand management where there is no specific unit when describing the discipline, giving priority to a negative, corporate, personal or reductionist style. This situation leads us to determine that we are facing a serious problem of terminological and structural confusion regarding this discipline (Fernández Gómez, 2013).

At an international level, we observe how the main experts in the field also identify the same problems noticed from the Spanish context, perhaps postulated many times in a more implicit way. What there is no doubt again is the atmosphere of terminological confusion that surrounds brand management, both in its definition and when determining its structure and different elements that make it up (Healey, 2009). It is almost impossible to find a standardized theoretical definition about what brand management is and what it means; on the other hand, the different conceptions that exist on the subject are evident: brand management (Keller, 2008), marketing (Aaker, 2014) or different reductionist views (Gobé, 2005; Klimchuk \& Krasovec, 2012) and/or commercial (Ogilvy, 2013). 
The problem of conceptual and structural confusion when approaching brand management unites the national and international levels, building a global reality. The axis of the professional sector and the academic field tends to try an approach with the passage of time, but today, and generally, we can assume that there is a significant gap between both concepts. Benavides (2017) insists on the idea of working together in the investigation of the phenomenon of brand strategy and its communication process, in order to seek consensus between both sides that suppose a transversal benefit and an advance in knowledge. Publications around brand management that are made from the professional sector tend to a disclosure from a purely commercial or personalistic perspective. This type of publications also has a tendency to beautify corporate success cases, hiding in the privacy of the agency (department or professional) exclusively the true data referring to methodologies, structure or ways of understanding the discipline. With regard to the academic field, it is usually far from the professional sector and there are many theoretical approaches without making an exhaustive contrast with the professional reality (Fernández Gómez, 2013). In any case, it is necessary to share work, objectives, methods and cases that lead to valuable research to improve professional efficiency, pedagogical understanding of the discipline, teaching in brand management, and the training of students who in the future will be specialized professionals.

According to the above, we will propose a stepped structure of specific objectives that will ultimately lead us to the resolution of the general objective in the form of working hypothesis. This means that it is necessary to give content and constant information to solve small approaches, which means that we will be able to create an amalgam of empirical arguments that end up constructing a theoretical story capable of refuting or ratifying the hypothesis. In coherence with the structure of the research (which will be resolved in an ascending way) we will expose the objectives in a descending way:

- Hypothesis: Brand management must be shaped as an eminently strategic process.

- General objective: Understand the conceptual, structural and organizational nature that makes up the brand management process.

- Specific objectives:

- To build a definition that helps us understand what brand management is.

- Identify the structure, elements and organizational base that shapes the brand management process through its main characteristics.

- Knowing the history of brands and their management process.

- Establish disciplinary theoretical basis on which brand management is based.

Staged structural development of the study:

- Specific objectives.

- General objective.

- Hypothesis.

To carry out the study empirically, completing each of the staggered stages in which it is structured, we will use as a methodological tool the bibliographic and documentary 
review. Without forgetting the foregoing, we will seek to obtain first-hand information from various sources, advocating the plurality and multidisciplinary dynamism that a subject such as brand management requires. In this way, we will cover the theoretical production that takes place around the discipline from the two axes mentioned: national bibliographic contribution (Spain) and international (global) both from the academic perspective (researchers and teachers) and from the professional sector (professionals, departments and organizations).

\section{Disciplinary theoretical basis}

The first step we are going to take when defining the study of brand management is embedded in its disciplinary concept. There is a huge diversity within the bibliography consulted about the discipline, outlining multiple points of view and different perspectives. Three major disciplines stand out in a compositional exercise that, based on scientific strength, help to shape brand management:

\subsection{Management}

The corporate reality of an organization requires a constant, transversal to all its elements, such as planning and administration through a large management process. Within this reality should be perfectly aligned the different structures of the company, from the economic area to the commercial one, going through the administrative, computer or organizational areas (Keller, 2008).

The development of the organization chart of a corporation, choose the necessary departments, establish the most effective direct relationship channels, choose the best professionals in each position to develop the activity in an efficient way, or adapting the activity of managers so that their action filters transversely throughout the daily work are transcendental issues related to management. We are not talking about a closed and immobilized work where changes take place in a slow and totally vertical way, but a composition of planned and orderly work that is dynamic and easily adaptable to change (Hansmann \& Kraakman, 2017).

The work of management extends through all the tentacles of the corporation, connecting the material, human, economic and computer aspects with more commercial facets that bring the brand closer to different publics such as public relations, branding, communication or marketing. The planning of all this work depends on the capacity to establish processes where the strategy is erected as a fundamental element (Johnson, Scholes \& Whittington, 2008). In this sense, it is essential that the organization be aware of the importance of management and start up a department, human or professional group responsible for the direction of the brand. 


\subsection{Communication}

Communication becomes another essential disciplinary factor within the bibliography of experts consulted. A large number of works and theoretical contributions use communication as a key discipline when analyzing and shaping brand management.

Communication is understood as a transversal element that covers all actions, internal and external, that are developed by the corporation. It contributes vitally in the creation of a certain brand image (Pomering, 2017). The relationship between employees, departments and different suppliers; communication with the public and in all the contact points of the brand; corporate communication and public relations; the transmission of information between the different elements of the organization chart of the company; customer service; relations with public and private institutions; strategic, commercial and / or advertising communication, etc. All these issues depend on good communication management, and what is more important, on the fact that communication is given the transcendental importance it requires.

Steyn (2004) explains that integrated brand communion plans, announcements, promotions or corporate communication actions must be subject to a well-defined strategy drawn from the brand management in order to be coherent (in the concept, content and aesthetics) and efficient (when connecting with the target). Equally important is planning and strategy when managing communication within the corporation's internal scope (Steyn, 2004).

\subsection{Marketing}

Marketing is positioned as the third major disciplinary pillar when it comes to tackling the study and understanding of brand management. We are dealing with a discipline that organizes and develops all the work previously reviewed in the areas of management and communication with the aim of, through strategic planning, build an adequate offer with respect to what the potential target of the brand demands (Baker, 2014).

Integrated Marketing Communications present the development of a comprehensive program that aims to strategically plan the actions that are going to be carried out from the corporation in order to project a certain image on the public through the construction of a commercial brand unique and perfectly differentiated from competitors. In this area, the relationship between the brand management, or the marketing department, and the rest of the departments is essential to develop actions successfully (Armstrong, Kotler, Harker \& Brennan, 2015). Once again, we enter the field of integral organization where management, communication and marketing come together and intertwine.

The marketing discipline introduces in its process the need to have a metrics table extracted after the realization of a constant measurement, filtered in an index of results of the different actions carried out by the brand (Farris, Bendle, Pfeifer \& Reibstein, 2017). There are a number of brand measurements that are general and are accepted in some way in the sector 
(image, reputation, brand health, etc.) and there are other customized that brands usually establish for more tactical issues through the implementation of KPIs. In any case, ROI, return on investment, it is the most searched variable for more purely commercial marketing actions and investments. This systematization of metrics becomes a fundamental element when establishing an eminently strategic process (Cerviño \& Baena, 2014).

\section{History of brands}

Taking management, communication and marketing as a disciplinary basis for analysis, we will approach brand management in the first place from a historical perspective. To understand the present and adapt to the future, it is necessary to know the past of brands. We are going to do a bibliographic review that puts us in a chronological perspective.

\subsection{Prehistory of the brand}

Brands have been able to adapt to the human needs civilization after civilization throughout the centuries. While in the beginning brands do not have a purely commercial sense as we understand them today, it is true that from that beginning they are linked to a functional utility of identification and differentiation. Joan Costa points out that the original birth of the brand is historically linked to the use of the marking technique as a physical fact of marking by incision, or by exerting pressure on moldable surfaces (Costa, 2004).

In Ancient Egypt there are numerous objects marked with different signs of identity associated both to the religious sphere and to an incipient commercial growth around the Nile River. The market activity that is generated manages to spread throughout the territory thanks to the persistence to open new roads that will facilitate the communication of people and the transport of merchandise (Saravia \& Amorim, 2009).

The Phoenicians are also capable of deploying a strong commercial traffic, giving an important qualitative leap in the development and technification of maritime transport. Thanks to their progress in techniques for the construction of ships they will master the art of navigation with skill, which will allow them to connect by sea with other towns, initiating an intense commercial relationship. In these circumstances, the Phoenicians will begin to develop, in parallel with the art of navigation, a whole series of new communication techniques aimed at improving the relationship and understanding with their new friends / clients. In this way, they create a kind of primitive alphabet that the Greeks will perfect in the future. If something is going to stand out from the Phoenicians in terms of communication techniques, that is going to be their art linked to fire. Through these actions they are refining numerous notices that will serve the other towns to know their arrival and the possibility of starting different commercial exchanges.

The Classical Antiquity is going to verify the development of the transport and the communications between different countries, which provokes a very powerful boom of the 
commercial exchanges. Stable and lasting ties are established between different peoples, a question that helps to intensify existing traffic. Both Checa (2007) and Keller (2008) agree in attributing to the prosperity of the period the development experienced by the use of stamping as a trademark technique for merchandise. Such is the commercial implosion that begins to use the metallic pattern as currency of exchange in transactions. This reality accelerates the need for sellers to mark the goods in order to be identified and recognized by their buyers. We are at the birth of the trademark. We must bear in mind that this was not based on the product, which is the true object of economic exchange, but on its packaging. What was marked in antiquity was not the good, but its container (Costa, 2004). The work related to the trademark techniques affects mainly the amphoras, considered the most used containers to transport goods during this time.

After the birth of the first form of trademark, its expansion comes thanks to the conjuncture that arose in Ancient Greece. The polis is formed as a massive social space where a large number of people are concentrated, launching a series of businesses related to the food market, raw materials and an expanding sector dedicated to handwork. Within the polis appears the agora, understood as the public square that is located in the center of the city as the central nucleus of social, cultural, political and commercial activity. The polis facilitates the settlement of a whole series of primitive techniques directly related to advertising and propaganda whose objective is, in addition to publicizing different products or small craft businesses, to offer notoriety to new neighborhoods that have a recognized commercial activity (Madrigal, 2009).

Rome and the constitution of its Empire become the transmission belt of all commercial and communication advances experienced by brands up to that time. The main characteristic of this new structure is its ability to successfully implement a process of political and administrative unity: establishes a common language, Latin; a spectacular communications system is constructed with thousands of kilometers of roadways, in addition to frequented sea routes; legislative unification is gestated around the emergence of Roman law that leads to another unification, which occurs in the religious sphere (Checa, 2007). The principles of commercial law developed in Rome will try to guarantee the validity of identification marks in amphorae or in any other type of container object whose purpose is the commercial transport of goods between different places (Keller, 2008). More than six centuries of unification provide the metropolis an endless number of new products and goods with which to trade. The extension of the empire also creates different strategic points where important population centers are formed, creating a kind of network or system where transport and commercial activity will have a frenetic activity. This situation facilitates a notable advance in terms of different commercial and advertising communication techniques (signage, product packaging, nomenclature, use of small slogans, etc.), and improves those taken from the Greek polis (López, 2001).

After the fall of the Roman Empire, the commercial system that had been established over time thanks to the close relations between the peoples of the Mediterranean, and many others of the interior Europe, was cracking to reach an obvious state of involution. In spite of this unflattering reality that is beginning to take shape, trademark techniques are going 
to be preserved, reduced in this case to an eminently local trade environment. We enter fully into the Middle Ages. Parallel to the crisis experienced by the trade, an alarming loss of importance of the cities is generated. We are faced with centuries of isolation and poverty where the castle replaces the forum (Checa, 2007). The consequences that come from this conjuncture cause a return to a subsistence economy where the exchange of products through barter returns to consolidate. A tight and absolutely hierarchical political system is imposed. The church and its governing bodies appear as new agents that control the public, cultural and commercial life of society. For a moral issue, the High Middle Ages relegate to ostracism all those jobs connected to trade, especially those activities related to advertising and propaganda. Ostentation and the enrichment are persecuted, reason why the commerce is going to be very affected by these circumstances.

The Late Middle Ages will bring with it a remarkable change that occurs gradually. The city in Europe reappears, becoming the perfect breeding ground for the emergence of civil institutions of undeniable historical relevance such as the university or banking (Pirenne, 2015). Associated with this new urban fervor is a corporate system, that of the guilds, which will lead the defense of property rights and the revitalization of commercial activity. There is a disruption that transports us from a feudal and decadent society to a new guild society that gives life to cities again. The conditions prevailing in this period (noble, feudal, armies and guilds) lead to heraldic art to an unusual relevance in the activity of marking, signage, visual identity and recognition. Joan Costa identifies these characteristics as the second birth of the brand.

\subsection{Modern Age}

The balance between the new corporate trades, which make up the structure of the guilds, and the classic feudal power is complicated. The relations between both agents is increasingly tense and they are moving towards armed confrontation due to the countless situations in which grievances and reproaches are exchanged. What is at stake is the acquisition of a new status of power against those who maintain their privileges. It reaches a point where institutions do not find their place in the new society that springs up against the withering medieval power. All this tension leads to confrontation and combat. The Middle Ages will come to an end after an irrepressible popular upheaval that culminates in an uprising. This conflict erupts in several French, Belgian and German regions that were dominated by the armed insurrection of the trades (Costa, 2004). The uprising puts an end, to a great extent, to the prevailing socio-political and economic status quo within this historical context in order to give way to a new way of understanding the world.

In the middle of the 15 th century, the use of the Gutenberg printing press expanded, which meant an authentic revolution. A new stage is set in motion. In the XVII century, with the Modern Age settled, the freedom of commerce is proclaimed and with it the boom of the industry. Economic liberalism emerges with strength (Hobsbawm, 2009). The characteristics of the new socio-economic context cause that the medieval corporations were dismantled along with their distinctive signs. A conjunctural transformation takes 
place that changes the system from its structural base generating a very remarkable economic success where the agrarian and artisan economy, with the Industrial Revolution, gave way to the production economy (Costa, 2004). These important changes take us to a context where the third birth of the brand arises, which becomes an optional property and its owner is responsible for its exploitation provided that it does not fall into any type of illegal behaviour. Mass production and chain processes are extended. Together with this situation, cities and urban centers grow around industries. A new class emerges, the worker, who has a salary to devote to consumption associated with improvements in living conditions.

The implantation and development of the written press, understood as a mass commercial media, is key to understand the incessant advertising activity that is going to be generated within this period. In any case, the editorial or argumentative announcements, which are the primary basis of the activity, will not arrive until the beginning of the 20th century. In the United States, a utilitarian economic model is imposed in the press until the newspaper's directors, Benjamin H. Day and James Gordon Bennett, decide to reduce the price of the newspaper according to a study that leads them to deduce that the number of readers will be what finally ends up attracting publicity to the media (Checa, 2008).

Following with this renovating business model, B. H. Day creates The New York Sun where, in addition to lowering the price of the newspaper, he innovates through the street vending technique which gives him a large number of traffic and prestige. A new business model is implemented that guarantees the viability of the mass media (reaches a large number of readers/consumers) through advertising (Gomis, 2008). The discipline is consolidated as a new rising professional sector that manages to respond to the demand generated. We are facing the starting point of a frenetic advertising activity that is consolidated with the appearance of various agencies at the service of creating great brands.

At the end of the 19th century, the economy underwent a remarkable process of expansion that led to its internationalization, without ever being globalized. The end of the Civil War raises a series of political and socioeconomic consequences that will be present until well into the twentieth century in the United States. This situation causes important business forces to unite to ensure that products with a manufacturer's brand and a broad distribution capacity are transformed into profitable national companies that reactivate the market (Keller, 2008). With the arrival of the 20th century, and thanks to the economic and industrial situation, advertising tends to become more sophisticated. Psychology goes on to play an essential role as a basis for the construction of a discipline with empirical packaging, scientific advertising. The psychologist Walter Dill Scott is one of the pioneers in the development of this trend to which many professionals from other branches of knowledge will add.

From the early twentieth century and until the great crisis of 1929, when the Crash of the New York Stock Exchange exploded, there are three decades of meteoric rise of advertising on the back of the American economic and commercial boom. Job conditions are very favorable for the American population and their purchasing power is increased. 
The manufacture of mass products and the advertising claim lubricate the consumer belt generating a significant progress in sales volume (García Uceda, 2011). In this context, advertising agencies will experience great growth, not only in their national dimension and activity, but also as important multinational companies opening branches in the main European countries. This situation favors both the recognition and the prominence of the products within the market, establishing themselves as the reference brands of the companies where they are produced.

After the Great Crash of 1929 the American economy suffers a great depression, accompanied by the decadent international post-war situation. Advertising tries to recover from this situation through investment in research that provides relevant improvements in the sales results of its customers. The agencies and the corporations themselves create research departments where the work of expert psychologists stands out. All the effort of the sector to endow the publicity of a scientific framework serves so that the discipline achieves a professional prestige that until then did not have. An example of this activity is the conformation of the technique known as the sales argument of Albert D. Lasker, on which both Claude C. Hopkins and John E. Kennedy investigate and develop their studies. Forged inside the Lord \& Thomas Agency, the sales argument will become popular within the sector thanks to Hopkins throughout the 1930s with the name "Reason why" (Checa, 2007). Try to give prominence to the product with an advantage or argument that makes it unique and different from competitors.

The scientific activity attached to what to do of the advertising sector, strengthened by the research departments, begin to provide professional work of a high strategic level. From the union of all these elements emerges, also at the beginning of the decade of the thirties of the last century, brand management. Neil McElroy, responsible for the advertising of Camay soap, belonging to Procter \& Gamble's product portfolio, elaborates a set of rules in the form of a memorandum in which he formulated the concept of brand management understood as a system of control and organization of the brand that will become an essential reference for all companies until today (Keller, 2008).

The decade of the forties brings with it an unfortunate international memory due to the outbreak and development of World War II (1939-1945), especially for Europe that is mired in a serious social, economic and political crisis. The other side of this inhuman contest is placed on the level of communication and propaganda, areas that will suffer a level of development and improvement never seen before, managing to apply an influence on the masses unthinkable until that date. Once the war ended, in the mid-1940s, the United States used its position to boost the revitalization of its national economy and establish a chain production based on multiple military-type techniques. The development of the field of communication and advertising is also taken advantage of by the North Americans to strengthen a very powerful sector that will live golden decades, full of changes and successful growth. New uses and functions associated with the advertising business are launched. This restates the nature of the discipline and directs us towards the birth of the so-called rationalist advertising, through a new technique called the Unique Selling Proposition (Reeves, 1997). As we expose, the end of the decade of the forties is especially 
productive in the United States for the birth of new advertising techniques that focus on the functional role of the product, and the technification of processes, such as the case of copy strategy: it arises in Procter \& Gamble with the intention of joining the objective of the advertiser with the work of the agency to achieve it in a strategic way and registered in a working document (Fernández Gómez, 2013).

The fifties bring with them a dualism between rationalist advertising and the use of the Unique Selling Proposition (Rosser Reeves and Al Rise) as a clearly dominant position on the one hand and the emerging and still very minor theories of the image (Cheskin and Martineau) by the other, all within an expanding sector. Television ends up being confirmed throughout this decade as the communication media most consumed by the vast majority of citizens. This fact causes that a specific advertising style has to be created for the television, the spot that abandons the detailed reasoning, the explanations of use and the abundant data to look for the simplicity, the concretion and in a gradual way the suggestion (Uceda, 2011). The agencies are in a golden age, forming a very powerful sector where large expansions are made both in the national market and globally (especially in Europe).

The decade of the sixties is going to be known as the era of products, establishing a strong North American middle class with economic capacity to consume and improve their standard of living. The economy works well and that affects the market through all the agents that are part of it. In the same way this decade is going to bring evolutions and notable changes in different areas such as cultural, social, political and economic. Throughout this decade, the theories about the image will gain greater strength, managing to pose a battle against rationalist advertising for the status quo of the way to understand the advertising discipline. Theodore Levitt states that rational sales arguments are saturated and fail to differentiate some products from others. The image manages to endow them with a power of differentiation and originality that goes beyond even the aesthetic, reaching the level of intangibles. Television greatly affects this paradigm shift when it comes to understanding brands. Under the demands of the industry, progress is made in the methodological and strategic aspect of the processes thanks, mainly, to the activity generated through the field of research.

At this juncture, Edmund Jerome McCarthy raises marketing as a discipline. Commercial management begins to demand that experts take charge of drawing up efficient sales strategies with the aim of improving the marketing of their products in all possible ways (including advertising). It also seeks to control the relationship between expenses and investments in order to be viable ensuring the profitability of the company. This specialization generates an increase in the knowledge of society and its modes of consumption. The technique will be refined with the emergence of the marketing 4Ps (product, price, place, promotion) that will later become the marketing mix process (Armstrong, Kotler, Harker \& Brennan, 2015). The hippie movement, of strong anti-war and counter-cultural convictions, which was generated at the end of the 1960s, shows a strong discontent with the system in general and with advertising in particular. The theory of the image, and especially the creative revolution of William Bernbach, also uses criticism, the desire for change and adaptation to a new world that was flourishing. The image and the intangible power that transmits its aesthetic wins the game to rational advertising. 
The paradigmatic change becomes really effective in the seventies, when the sector adopts the techniques developed from a conception of image theories, adapting them to reality and existing media. The middle class, the consumer society and television (mass media communication) are consolidated. The problem of competition and saturation appears. This situation forces the departments and agencies to go one step further in their research works, developing different techniques that help to improve the knowledge of their target: the focus and the consumer profiles (primitive and basic at the beginning, more extensive and exhaustive with the passage of time). A new technique, strategic audit or SWOT analysis is added to this procedure, which seeks to detect the main forces, weaknesses, opportunities and threats of the corporation in order to make the most appropriate strategic decisions to successfully meet the objectives established (Chapman, 2004).

The strategic action that the sector applies to their professional work reaches a symbolic milestone thanks to the publicists Jack Trout and Al Rise, who create the technique of positioning. They focus on establishing a symbolic place for the product / brand within the consumers' brain; strategic messages are constructed with the aim that they become a certain series of perceptions to create a certain positioning (Trout \& Rise, 1986). This technique is so relevant that it will be able to adapt itself to the circumstances until it becomes fully valid to our days. It unites a functional and rationalist tendency to enter the psychological and strategic terrain of the intangibles (theories of the image).

The conjunctural circumstances and the development of increasingly complex strategic techniques evidence the aforementioned paradigm shift; the action of rationalist publicity fades before the psychological and aesthetic power of image theories that go beyond the purely rational plane to inquire into intangible planes such as feelings and perceptions. The technique that takes all this baggage and becomes the vanguard within the sector when developing professional work is the brand image. The product/brand is endowed with a very specific aesthetic that provokes a series of perceptions to its target; the public associates the received information with a certain image (Ogilvy, 2013).

The decade of the eighties is based on the welfare society. Technology begins to have an increasingly relevant role. The concept of the image is imposed on the rational idea associated with the product. The marketing and advertising specialists of many corporations are aware of the enormous strategic value that the brand has as an entity that goes beyond the logic associated with the product. Television becomes the great mass media to which the highest percentage of advertising investment is destined. The brand image achieves the greatest role as a star technique within the sector, knowing how to adapt in any of the cases to the conjunctural changes that are taking place. Corporate policies evolve in order to adapt to the new reality. The management will raise a technique of British origin that had been born more than two decades ago with the aim of improving the processes of administration and decision making. It is about strategic planning, a tool that takes into account the vital importance of strategy within organizations through a methodology that achieves a coherent alignment of both the organization and its offer around a common goal towards to launch the brand. 
In the nineties, media and information society is consolidated. Television enlarges its role and develops different business models in order to adapt its offer to the general public as well as to different niche audiences. Since the late eighties, the growth of large corporations has led to strong purchase, merger and acquisition operations. In this context appears a global economic crisis that forces many other corporations to close. The crisis has a great impact on the advertising sector, from the economic sphere to the techniques and methodologies used. Added to this situation is the problem of competition, technological development and, above all, saturation. Under these circumstances, companies will make a significant commitment to enhance the brand and its intangible characteristics, while developing strategic techniques related to the field of advertising and marketing: planning, identity and brand value, integrated marketing communications and BTL actions (in addition to the classic ATL). This sum of techniques and elements delves into the strategic and professionalized approach towards which any management process of a brand should aim.

The end of the nineties, and the beginning of the 21 st century, presents a series of really rapid disruptive changes that lead us towards a new paradigm. The technological advance and the democratization of the Internet are key to understanding the new context. Users are increasingly trained and reject intrusive commercial communication while establishing new modes of information, communication, consumption and purchasing decisions that greatly influence their way of life. This conjuncture gives full powers to consumers, a new center of action towards which corporate policies are directed; the brand becomes an undoubtedly protagonist that, in addition to being the most important tangible / intangible asset of the companies, it becomes the main communication / connection tool with its public generating unique and relevant experiences that add value and move away of intrusive actions (Ortegón, 2017).

We are entering the field of big data and almost individualized micro-segmentation. Those brands that fail to adapt their communication and strategy to this new paradigmatic reality tend to lose their contact with reality and its relationship with the target. In their undeniably leading role, brands manage to transcend the corporate and commercial scope to establish themselves as authentic social, cultural, economic and global icons charged with identity, personality, symbolism, values and representation of very different lifestyles that build us as a social collective (Alameda, 2016). Faced with this new paradigmatic reality, which increases the number of possible elements of administration and communication, the strategic and professionalized process of brand management reaches a totally decisive relevance. Likewise, it is necessary to adapt the most traditional advertising to reach certain niches, using new techniques based on engagement, leisure, and relevant content, especially branded content and story doing.

\section{Characteristics and definition of brand management}

It is essential to know the past, and be aware of the present conditions, to be able to adapt successfully to what comes in the future. This strategic idea pursued by management in their professional work is fundamental when it comes to managing a brand. The historical and bibliographic review done previously puts us in background, giving perspective when 
carrying out an analysis of the brand management process. In the first place, we must take into account the global problem that exists around the study, delimitation and definition of the concept of brand management, indicated by the main experts in the field. The confusion extends throughout the professional sector, in the academic field and through published bibliographic production. Precisely because of these circumstances, it becomes even more essential to approach the discipline from an open and plural position where it is easier to identify a series of common characteristics, above reductionist or individualistic positions.

\subsection{Integral process of multidisciplinary nature}

Abraham Maslow affirmed that human beings perceive things better integrated into categories than as isolated elements. This idea is what allows us to understand the need to start a management process that accomplishes to integrate all the elements that make up the brand, giving them a coherent alignment with each other so that the brand is perceived correctly as a whole full of meaning (Ellwood, 2009). Both, the elements that are part of the management process and the disciplines that shape it, are complex and diverse. This fact confirms that we are facing a multidisciplinary process that must be managed in an integrated manner. For that reason, it is so important to make the process a harmonious, coherent and unifying system. The theoretical development that promotes brand management from an integrated perspective is based on the construction of a holistic system. Pascal alluded to the impossibility of knowing the parts without knowing the whole, and it was not possible to know the whole without knowing the parts previously. Costa affirms that holism, or the psychological theory of perception (Gestalt), denies the Cartesian duality of the whole and the parts, and proclaims that the whole is more than the sum of its parts. And that the whole is not possible to reduce it to parts because they are all interdependent and that is how they make sense when forming the whole (Costa, 2013). These ideas fit perfectly with the process of strategic brand management that, based on the integration of multiple elements, forms a unique and recognizable offer through the brand. The essence of holism is that it progressively integrates levels of interaction and leads to global ideas; a holism that involves transversality and overcoming reductionism.

Culleré (2013) unites all the characteristics reviewed and puts them in common through an integration exercise. He points out that the imaginary of the brand is a single, inseparable and immaterial whole, according to the holistic nature that shapes and defines it, and in which, at the same time, the brand is the whole and the parts. In order for this integrated concatenation of elements to be harmonious, it is vital that brand management be truly established in the internal processes of the company and involve all the people in the organization. Therefore, the exercise of branding requires a global vision and capacity to articulate actions and disciplines of a diverse nature.

The holistic vision of the process is constructed through a systemic approach, understood as a network strategy where each element of a system is defined by its relationship with the elements of the same system and the system with other systems forming a network (a series of points linked by a series of relationships that meet certain properties) (Benavides, 2017). 


\subsection{Specialized professional discipline}

The need for a strategic approach to ensure the efficiency of the management process of a given brand forces managers to look for a professional or team of specific professionals exclusively in charge of creating a firm, clear and rich identity, as well as achieving that, both inside and outside the company, understand that identity (Aaker \& Joachimsthaler, 2012). These professionals must meet a profile of a specialist who manages to extract, study and disseminate relevant information, in addition to making important decisions regarding the implementation of the strategy within the organization. For this, the brand director is presupposed by a series of extensive knowledge that will allow him to make leadership decisions and direct conflicts, people, projects, strategies, implementation actions and the uncertainty associated with the change.

It is necessary to have the possibility of knowing and managing all the elements, channels, resources and agents that are part of the offer, which means that, in one way or another, they are an essential part of the brand management process (system holistic). This fact represents a step forward in the professionalization of the brand, abandoning completely fragmented ways of acting. The specific professional activity in charge of brand management must maintain the continuity of the work and remain coherent in order to sustain the strategic concept over time, which implies assuming that this work begins with the brand's own conception and is extended cyclically through its existence (Crainer \& Dearlove, 2004).

The complexity that surrounds the process of brand management represents a challenge for the professionalization of the discipline, and for the specialized training of its professionals. For this reason, work teams are increasingly multidisciplinary in order to lead to a methodology of collaborative work away from both improvisation and confusion. This vision is common to the vast majority of experts in brand management, the only thing that changes is the perspective from which the discipline is approached.

\subsection{Provide value to the brand}

The brand has multiple dimensions (corporate, economic, symbolic, social, commercial, etc.) but in all of them it is the most important asset of the organization, which gives it great value. The strategy and the management actions have to be directed towards a good administration of this variable in order to increase as much as possible, and over time, the perception of value that consumers have about the brand. Aaker affirms that the value of the brand constitutes a group of strengths or assets such as the recognition of the brand, customer loyalty, perceived quality and associations that link the brand and incorporate value to the product or service offered. It is important to bear in mind that the development of a value system for the brand creates associations that lead to market positioning, are maintained for long periods of time and are capable of resisting aggressive competitors (Aaker, 2012).

In any case, the value of the brand is associated with a measure of analysis that concludes that the extra money consumers are willing to pay for a brand, compared to the offers of their competitors, is what determines the value. The added value that a brand achieves is the consequence of a 
brilliant strategic management work. The fact that brands, through their management process, must add value in each and every one of the operations they carry out and transform this into a higher value for consumers, must be taken into account at all times (Crainer \& Dearlove, 2004). In relation to this idea, Fazio Maruca (2005) denounces the little effort that many companies dedicate to the endowment of added value to the brand. Brand management can not underestimate the strategic importance of generating added value as essential power of the brand.

\subsection{Adaptation to the paradigmatic reality}

The brand management process must be proactive and dynamic at all times. This fact facilitates its intrinsic function of adaptation to the ever-changing conjuncture, assuming the paradigmatic reality of each moment. According to this principle, and as already mentioned in the previous point of this research, brand management process today.

\subsection{Puts the consumer at the center of the action of the brand}

The consumer becomes the protagonist agent that triggers the subsequent strategic decision making. This quality requires a deep knowledge of the target to which we direct our actions. The marketing research work concludes that the power of a brand is not in the products, in the category or in the market, but in the minds of its potential consumers (Keller, 2008). We are facing a paradigmatic reality in which, thanks to technological development, consumers have control in their hands and this requires a new approach to the way brands act.

\subsection{Connects the brand with its audiences in a relevant way through relationships based on unique experiences}

The new paradigmatic reality requires brand management to establish contact points that invite active participation in a comfortable and direct way, and in a relationship of equals. New technologies, to a large extent, are the consequence and solution to this new paradigmatic conception. Taking this reality into account, brand management must know how to apply strategic solutions and tactical implementations so that the brand adapts and does not lose its direct relationship with the public.

Brand management aims to go a step further in building connections with users by directly involving them in their process as agents of active content production, or elements of cocreation, through new techniques such as co-branding and the story doing. The process has to adapt constantly to the paradigmatic reality with the purpose that the brand can endure successfully over time.

\subsection{Coherence, perseverance and consistency}

The strategic management process gives the brand, through its multiple elements of connection with the target, with a series of symbolic and emotional meanings that constitute a specific personality in charge of transmitting identity. The main effort facing the discipline is to align all the elements of identity that are part of the brand 
to transmit a specific offer that is unique to the target and, subsequently, satisfy the promise made through the experience lived by the consumer.

Brand management must trace an identity, a concept, a personality, an image and a form of communication that is recognizable, unique to its target, and different from what is proposed by competitors. This requires a firm strategy where coherence, perseverance and consistency become essential elements (Clifton, 2009).

Among the characteristics associated with the process of brand management, identified through the bibliographic review of experts, stands out one that is transversal and complementary to all others:

\subsection{Strategic process (long-term vision)}

Brand management has gone from being a set of techniques and autonomous elements of tactical nature within the organization, or of its commercial communication process, to become a purely strategic and integrated issue. The professionalization of the discipline pursues the objective of adapting to the paradigmatic reality. Along with its nature of holistic type is intended to perpetuate an aligned view of the brand over time, making the strategy permeate across the entire activity. Crainer \& Dearlove (2004) point out, in relation to this idea, that it is essential to develop a long-term strategic vision so that the company can use its assets to manage the identity of the brand in the mind of the consumer (Crainer, 1997, p. 152).

It is evident that the management of a brand, and the perception that its public will have, is not something that can be solved successfully in the short term. This discipline requires strategy and long-term vision, both concepts are indissoluble and are linked to the very nature of the process. Depending on the characteristics of each brand, the management process will develop a specific strategy with a succession of ad hoc actions to implement it successfully over time around a series of objectives. In this regard, Kotler (2011) adds that there is no optimal strategy for all companies. Each one must decide what is best for them, taking into account their position in the sector and their objectives, opportunities and resources.

Ollé \& Ríu brilliantly condense the strategic nature of brand management associated with a vision set in the long term. In conclusion, they affirm that a strategy is nothing more than to locate economic, intellectual and time resources, pursuing a certain vision of the world (Ollé \& Ríu, 2009). This idea of strategy associated in an essential and transversal way to the brand management process is what makes it possible to link all the actions, elements and dimensions available to the brand, coherently aligning them under a common objective previously established.

Since we have a series of key features associated with the brand management process, which helps us to delimitate the discipline, we will also propose a theoretical definition of it. Pursuing the aim of advancing in the knowledge of the subject, and clarifying what 
we refer to when using the concept of brand management, we propose the approach made by the Spanish Association of Branding Companies (AEBRAND) which includes the main international / multinational agencies of the sector: It is the intelligent, strategic and creative management of all those elements that differentiate the identity of a brand (tangible or intangible) and that contribute to the construction of a promise and an advantageous, distinctive, relevant, complete and sustainable in time brand experience.

\section{Conclusions}

According to the presentation made throughout the research, supported by the bibliographic review of experts in the field, we obtain a series of certainties on which to elaborate an empirical argument that succeeds in responding to the objectives and hypotheses initially proposed. Taking into account the hypothetical-deductive logic of step type, we will go from the most specific to the most general:

\subsection{Specific objectives}

- The theoretical disciplinary base on which the brand management process is based rests mainly on management, communication and marketing trends. The strategic function runs through each of the three disciplines in an inherent way, just as it does in its function of administration and integral alignment around a common goal to all of them.

- The history of brands and the evolution in the techniques that shape their management process teach us that their main strength over the years is their ability to adapt to the prevailing situation. This idea in itself is impregnated in all its meanings by an eminently strategic and constant conception. The current paradigmatic reality, decisively conditioned by technological advances that lead to a phase of democratization through the Internet, enhances the prominence of brands and empowers users. In this situation, the brand management process acquires a vital importance in order to use and align the appropriate techniques to connect the brand in a relevant way with the user through unique experiences. In order to successfully develop this whole process involving numerous techniques, internal/ external persons/departments and elements, we need a sustained objective over time, under constant strategic action.

- In accordance with the problems and endemic confusion associated with the different theoretical approaches that take place around brand management, we have carried out a bibliographic review exercise in order to identify the main characteristics that are part of the discipline and contribute to shape it. The organizational structure of any brand management process is developed around the alignment of a series of elements pursuing a specific objective. The main features appearing transversely along the entire process of brand management are the following: 
- It is an integral process of multidisciplinary nature.

- We are facing a specialized professional discipline.

- The process aims to add value to the brand.

- A constant ability to adapt to the prevailing paradigmatic reality is pursued.

- The process must be impregnated at all times with coherence, perseverance and consistency.

- We are facing a strategic process where there is an objective or a series of basic objectives set in the long term.

- The identification of the main characteristics that are associated with the process of brand management help us to delimit it, facilitating its understanding. This fact facilitates that we can search among the consulted bibliography to approach a definition that goes in consonance with the exposed. The definition made by the Spanish Association of Branding Companies seems to us to be the one that best adapts to the characteristics identified, in addition to complying with the two axes of professional sector/academic field and local/global vision:

It is the intelligent, strategic and creative management of all those elements that differentiate the identity of a brand (tangible or intangible) and that contribute to the construction of a promise and an advantageous, distinctive, relevant, complete and sustainable in time brand experience.

Needless to say, the definition reflects the eminently strategic nature of any successful brand management process.

\subsection{General objective}

The stepped structure that permeates the methodological development of this research, allows us to have gathered enough information in the specific objectives part to have complied empirically with the general objective. We have achieved to delimit the process of brand management thanks to the knowledge of its historical evolution, the current paradigmatic reality on which it has to adapt, the main characteristics that give it shape and a definition that helps us to understand more clearly what we refer to when we talk about brand management. In any case, we observe how all the structural dimensions, elements, actions and variables that are part of the brand management process are influenced in a transversal way by the strategic action.

\subsection{Hypothesis}

Continuing with the step structure established by this research, we finally approach the hypothesis with information from the general objective, which in turn comes from responding to the different specific objectives. According to the information obtained, we can conclude that the work hypothesis proposed in this research is perfectly validated since it is completely true and correct to affirm that brand management must be formed as an eminently strategic process. Without strategy there is no successful brand management 
process. The strategy becomes the key transversal element that manages to coherently unite and align all the dimensions, elements and actions that shape the brand through its management process.

\section{References}

Aaker, D. (2012). Building strong brands. Nueva York: Simon \& Schuster.

Aaker, D. (2014). Aaker on branding. Nueva York: Morgan James.

Aaker, D. \& Joachimsthaler, E. (2012). Brand leadership. Nueva York: The Free Press.

Alameda, D. (2016). Marcas y culturas colectivas. Recuperado de http:// innovacionaudiovisual.com/2016/10/13/marcas-y-culturas-colectivas/

Armstrong, G., Kotler, P., Harker, M. \& Brennan, R. (2015). Marketing: an introduction. Londres: Pearson Education.

Baker, M. (2014). Marketing strategy and management. Londres: Palgrave Macmillan.

Bauman, Z. (2007). Liquid times: Living in an age of uncertainty. Cambridge: Polity.

Benavides, J. (2017). La gestión de las marcas y los valores en el turbulento contexto de la comunicación. International Journal of Communication Research, 16, 34-59.

Cerviño, J. \& Baena, V. (2014). Nuevas dimensiones y problemáticas en el ámbito de la creación y gestión de marcas. Cuadernos de Estudios Empresariales, 24, 11-50.

Chapman, A. (2004). Análisis DOFA y análisis PEST. Recuperado de http:// empresascreciendobien.com/wp/wp-content/uploads/2016/03/Manual-DOFA.pdf

Checa, A. (2007). Historia de la publicidad. La Coruña: Netbiblo.

Checa, A. (2008). Historia de la Comunicación: de la crónica a la disciplina científica. Sevilla: NetBiblio.

Clifton, R. (2009). Brands and branding. Nueva York: The Economist, Bloomberg Press.

Costa, J. (2004). La imagen de marca: un fenómeno social. Barcelona: Paidós.

Costa, J. (2013). Los 5 pilares del branding: anatomía de la marca. Barcelona: Costa Punto Com.

Crainer, S. \& Dearlove, D. (2004). Financial Times handbook of management. Edimburgo: Pearson Education. 
Culleré, A. (2013). El rostro de la marca. En J. Costa, G. Bosovsky, I. Fontvila, A. Rabadán \& A. Culleré (Eds.), Los 5 pilares del branding. Anatomía de la marca (pp. 107-134). Barcelona: Costa Punto Com.

Ellwood, I. (2009). Brand strategy. En R. Clifton (Ed.), Brands and branding (pp. 73-96). Nueva York: The Economist, Bloomberg Press.

Farris, P., Bendle, N., Pfeifer, P. \& Reibstein, D. (2017). Key marketing metrics: the 50+ metrics every manager needs to know. Londres: Pearson.

Fernández Gómez, J. (2013). Principios de estrategia publicitaria y gestión de marcas; Nuevas tendencias de Brand Management. Madrid: McGraw Hill.

Fazio Maruca, R. (2005). Cómo desarrollar una marca de élite. En Harvard Business School, Gestión de marcas (pp. 51-78). Bilbao: Ediciones Deusto.

García Uceda, M. (2011). Las claves de la publicidad. Madrid: ESIC.

Gobé, M. (2005). Branding emocional: el nuevo paradigma para conectar las marcas emocionalmente con las personas. Barcelona: Divine Egg.

Gomis, L. (2008). Teoría de los géneros periodísticos. Barcelona: UOC.

Hansmann, H. \& Kraakman, R. (2017). The End of History for Corporate Law. En L. Mitchell (Ed.), Corporate Governance. Values, Ethics and Leadership (pp. 49-78). Londres: Gower.

Healey, M. (2009). ¿Qué es branding? Barcelona: Gustavo Gili.

Hobsbawm, E. (10 de abril de 2009). Socialism has failed. Now capitalism is bankrupt. So what comes next? The Guardian, p. 33. Recuperado de https:/www.theguardian.com/ commentisfree/2009/apr/10/financial-crisis-capitalism-socialism-alternatives

Johnson, G., Scholes, K. \& Whittington, R. (2008). Exploring corporate strategy: text \& cases. Edimburgo: Pearson Education, Financial Times.

Keller, K. (2008). Administración estratégica de marca. Branding. Madrid: Pearson Educación.

Klimchuk, M. \& Krasovec, S. (2012). Packaging design: Successful product branding from concept to shelf. Nueva Jersey: John Wiley \& Sons.

Kotler, P. (2011). Kellogg on branding: The marketing faculty of The Kellogg School of Management. Nueva Jersey: John Wiley \& Sons. 
López, B. (2001). La propaganda oficial romana: Procesos, métodos y elementos. Eúphoros, 3, 189-220.

Madrigal, D. (2009). La filosofía en Grecia: sobre el encuentro mythos-logos. En C. Muñoz \& C. Morales (Coords.), La antigua Grecia. Sabios y saberes (pp. 1-23). Medellín: Universidad de Antioquia.

Ogilvy, D. (2013). Ogilvy on advertising. Londres: Vintage.

Ollé, R. \& Ríu, D. (2009). El nuevo Brand Management. Madrid: Planeta.

Ortegón, L. (2017). Gestión de marca. Bogotá: Politécnico Grancolombiano.

Pirenne, H. (2015). Economic and social history of medieval Europe. Londres: Routledge.

Pomering, A. (2017). Communicating CSR Through Corporate Image Advertising. En S. Diehl, M. Karmasin, B. Mueller, R. Terlutter \& F. Weder. (Eds.), Handbook of Integrated CSR Communication (pp. 171-190). Suiza: Springer.

Reeves, R. (1997). La realidad en la publicidad: un acercamiento a la teoría de la USP. Barcelona: Devilco Bates.

Saravia, A. \& Amorim, L. (2009). Influencia de la ingeniería en el desarrollo comercial de la humanidad: Edad Antigua. Revista de Ingeniería Lámpsakos, 2, 79-89.

Steyn, B. (2004). From strategy to corporate communication strategy: A conceptualization. Journal of Communication Management, 8(2), 168-183.

Trout, J. \& Ries, A. (1986). Positioning: The battle for your mind. Londres: McGraw-Hill.

Uceda, M. (2011). Las claves de la publicidad. Madrid: ESIC. 